\title{
ON W..GŠNG IN THE 4TH LINE OF THE WEST SIDE OF THE ŠINE-USU INSCRIPTION*
}

\author{
Li Yong-Sŏng \\ Department of Asian Languages and Civilizations, College of Humanities, \\ Seoul National University \\ 1 Gwanak-ro, Gwanak-gu, Seoul 08826, Republic of Korea \\ e-mail: yulduz77@naver.com
}

The Šine-Usu Inscription is the most voluminous one with 50 lines among the Uighur inscriptions. Although most parts of this inscription can be well understood, many words and sentences in the south and west sides are not so. These sides are now severely damaged. W..GšNG in the 4th line of the west side has been differently interpreted by researchers. The author regards $\left.{ }^{\prime}() Y\right\}(\cdots)$ W..GšNG

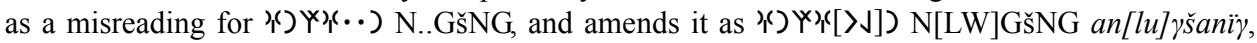
suggesting that the letter groups TKGWYILKA ..... N[LW]GšNGYWwKïKILms in this line

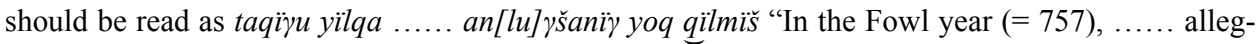
edly he (or they) eliminated Anluүšan (= An Lushan)".

Key words: accusative case, An Lushan, misreading, Moyun Čor, Orkhon Turkic, Šine-Usu Inscription, Uighur inscriptions, Uighur Khaganate.

\section{Introduction}

The Šine-Usu Inscription is the most voluminous one with 50 lines among the Uighur inscriptions. This inscription was found in 1909 by G. J. Ramstedt in the vicinity of the Mount Örgöötü, the Rivulet Mogoitu, and the Lake Šine-usu (Figures 1 and 2) (see Ramstedt 1913: 10-11). ${ }^{1}$ Like the Tes (750) and Tariat (752-753) inscriptions, the

* This work was supported by Strategic Research in Korean Studies through the Ministry of Education of the Republic of Korea and the Korean Studies Promotion Service of the Academy of Korean Studies (AKS-2016-SRK-1230002). It is an improved version of the paper presented at the symposium 'A Study of Transcriptional Data in the Scripts of Northern Ethnic Groups and Related Historical Documents of Relevance to Ancient Korean History' (24 July 2018) in Ulaanbaatar, Mongolia.

${ }^{1}$ Guided by a local man of a ger [yurt] near this inscription, we visited the burial mound on the top of the Mount Örgöötü on 1 August 2018. This burial mound was already raided by grave robbers. 


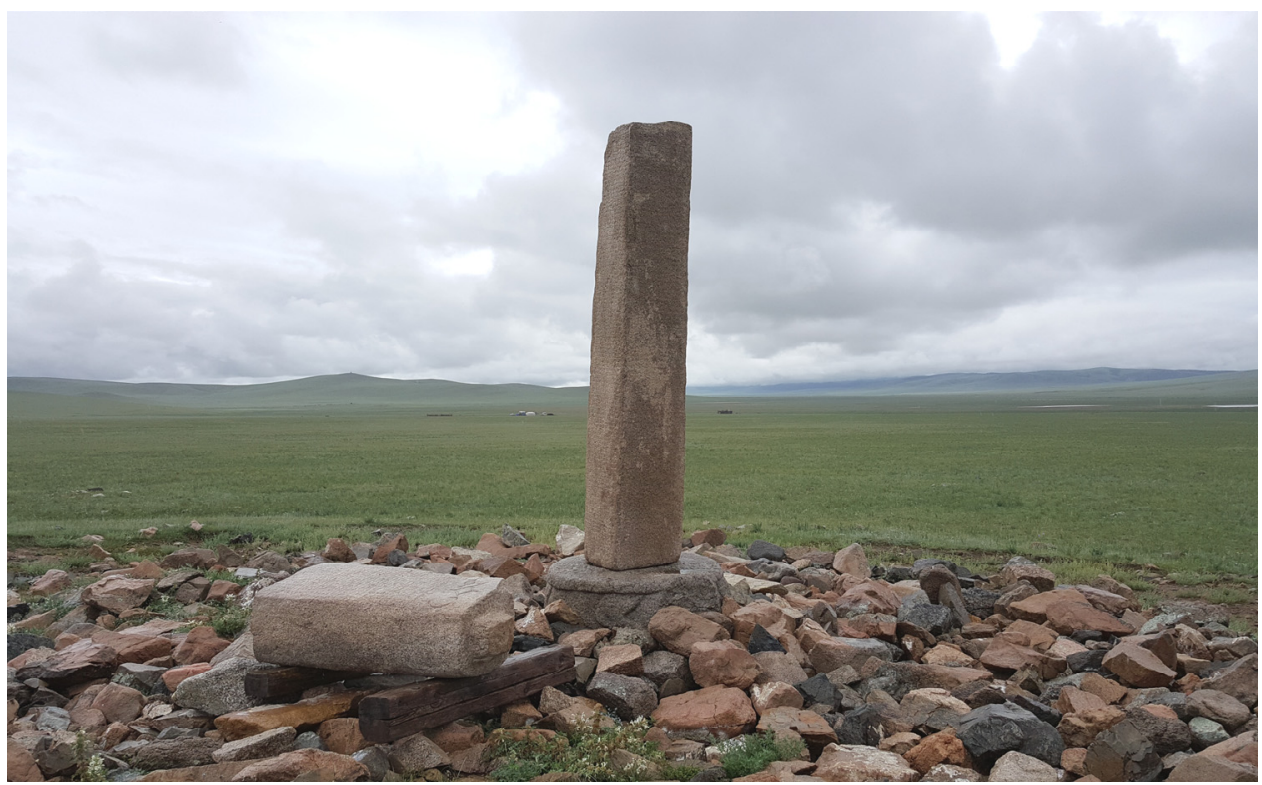

Figure 1. The Šine-Usu Inscription

(Co-ordinates of the photographing point: $48.54167^{\circ} \mathrm{N}, 102.21278^{\circ} \mathrm{E}$ )

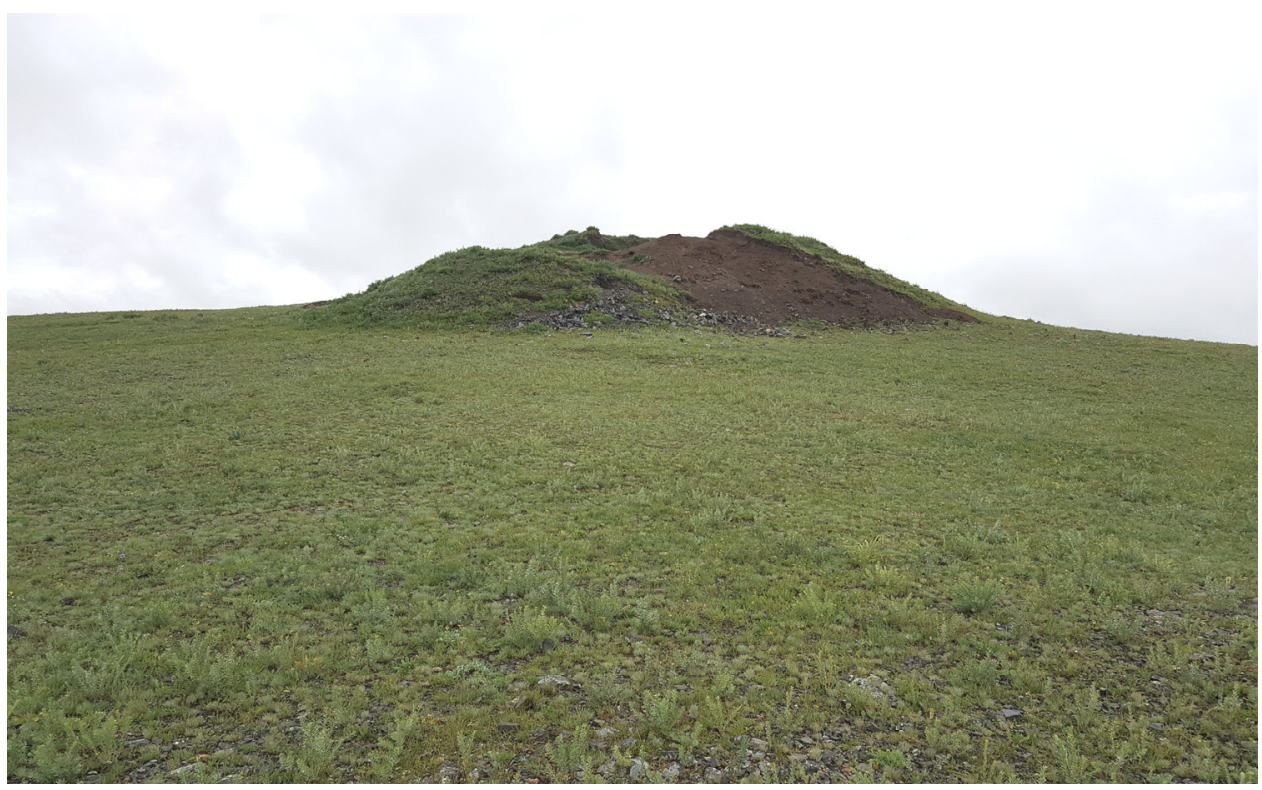

Figure 2. The burial mound on the top of the Mount Örgöötü (Co-ordinates of the photographing point: $48.58639^{\circ} \mathrm{N}, 102.22722^{\circ} \mathrm{E}$ ) 
Šine-Usu Inscription was also erected in 759 in honour of Moyun Čor (Moyanchuo 磨延嗓 ${ }^{2}$ ), the second kaghan of the Uighur Khaganate (r. 747-759). It is still on the spot of discovery in two pieces.

\section{Interpretations of $W . . G \breve{s} N G$}

Although most parts of the Šine-Usu Inscription can be well understood, many words and sentences in the south and west sides are not so. These sides are now severely damaged. ${ }^{3}$ The sentence containing the letter group $W \ldots G \check{s} N G$ have been interpreted differently so far: ${ }^{4}$

(1) Ramstedt (1913)

$:|\otimes J \Gamma \Delta \downarrow\rangle D)() Y)_{1}(\cdot \cdot\rangle:($ p. 34)

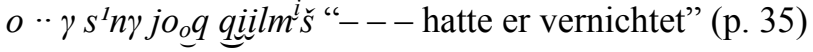

(2) Orkun (1936)

$:|\otimes J \Gamma \Delta \downarrow\rangle D)() Y)(\cdot \cdots\rangle:($ p. 181)

o ...g g ng yok $k 1 \mathrm{~lm}^{1}$ ş. (p. 180)

“.... yok eylemiş [allegedly he annihilated];” (p. 181)

(3) Malov (1959)

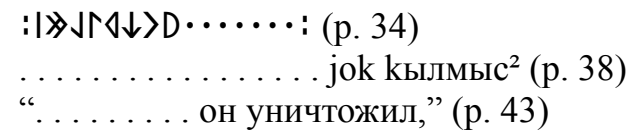

${ }^{2}$ mua -jian-ts $S^{h} y a t$ in Late Middle Chinese and $m a^{h}$-jian-t $6^{h}$ wiat in Early Middle Chinese. “... Early Middle Chinese is the language of the Qieyun [切韻] rhyme dictionary of A.D. 601, which codified the standard literary language of both North and South China, the preceding period of division. ... Late Middle Chinese is the standard language of the High Tang [唐] Dynasty, based on the dialect of the capital, Chang' an [長安]. ...” (Pulleyblank 1991: i); $j$ and $y$ represent $y$ and $\ddot{u}$ respectively.

${ }^{3}$ In this connection, Mert (2009: 202) reports as follows: "Because the south side of the inscription shows excessive wear, it is difficult to follow the historical information described and to make a relationship between words and sentences.... There are 10 lines of text in Turkic Runic script on the west side that is much worse than the other sides. In the parts remaining intact of the west side where all of those described could not be detected due to excessive wear, ... [Yazitın güney yüzünde aşırı derecede yıpranma olduğundan anlatılan tarihî bilgileri takip etmek, kelimeler ve cümleler arasında ilişki kurmak zorlaşmaktadır. ... Diğer yüzlere göre çok daha kötü durumda olan batı yüzde 10 satırlık Köktürk harfli metin bulunmaktadır. Aşırı yıpranma dolayısıyla anlatılanların tamamının tespit edilemediği batı yüzün sağlam kalan kısımlarında ....”."

${ }^{4}$ Researchers used different languages and transcription/transliteration systems. The author tried to give the reading of each researcher chronologically and just as it is. The interpretation of each researcher is arranged in the following order: (1) the text in Turkic Runic script (or the transliterated text); (2) the transcription of the text; (3) the translation of the text.

${ }^{5}$ All the Turkic Runic letters are in exactly the opposite direction. 
(4) Ajdarov (1971)

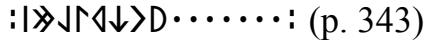

. . . йоқ қылмыс “. . .он уничтожил,” (р. 352)

(5) Moriyasu (1999)

:(W)nč(R)GšNGYWuQïQiLms: (p. 181)

/ / /- $\gamma$ yoq qïlmïš (p. 181)

"I heard that he annihilated a promising*****." (p. 185)

“彼は前途有望な*****を滅ぼしたという.”(p. 189)

(6) Berta (2004)

: W...GšNGYWwKïKILms : (p. 280)

... yoq qïlmï̌s (p. 298)

“... megsemmisítette (állítólag) [(allegedly) he annihilated]."6 (p. 313)

(7) Jeong (2005)

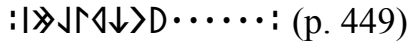

yoq qiilm(i)s (p. 449)

없게 되었다 한다 [allegedly (he) became nonexistent]." (p. 449)

(8) Aydin (2007)

: W .. GşNGYWwKK1ILms : (p. 32)

$\mathrm{o} / \mathrm{u} . . \mathrm{g}^{1} \mathrm{~S}^{1} \mathrm{n}^{2} \mathrm{~g}^{17}$ yook ku1 $1 \mathrm{~lm}$ ıs (p. 54)

“... yok etmiş [allegedly he annihilated].” (p. 63)

(9) Moriyasu et al. (2009)

:(W)nč(W)Gšñ GYWuQïQiLms: (p. 19)

onč uүuš añi $\gamma$ yoq qïlmïšs ${ }^{8}$ (p. 20)

${ }^{6}$ This sentence was translated into Turkish as "... yok etmiş [allegedly he annihilated]”, see Berta (2010: 303).

${ }_{8}^{7}$ An editorial error for $\mathrm{g}^{1} \mathrm{~s}^{1} \mathrm{n}^{1} \mathrm{~g}^{1}$.

8 “W4, onč ưuš añï yoq qïlmiiš: ラムシュテット版 (Ramstedt 1913, p. 34) でも旧版で

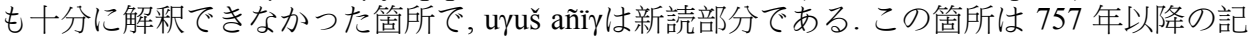
事で，ちょうどウイグル軍が安史の乱に介入していた項に対応する. ončの解釈ができない が, 唐王朝側あるいは安史勢力側いずれかのある u あろう. 安史の乱における唐 とウイグルの動向については, 森安 2002, pp. 130-134を參照. Kamalov 2001 でも同じテーマを报うが，史料の読解にやや誤りがあるので注意されたい.”

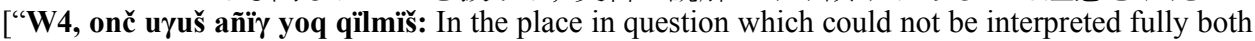
in the publication of Ramstedt (Ramstedt 1913, p. 34) and in the old edition [of the publication of the author], uүuš añï is in the part of new reading. This place in question is the news after the year 757 and corresponds exactly to the section concerning the intervention of the Uighur Army in the An-Shi Rebellion. Although the interpretation of onč is impossible, uүuš 'a clan' belonging to either 
"I heard that he annihilated ***** clan thoroughly." (p. 31)

“彼は???一族をひどく滅ぼしたという.” (p. 40)

(10) Mert (2009)

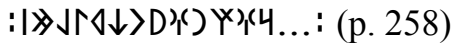

:......rg

“......... yok etmiş [allegedly he annihilated].” (p. 262)

(11) User (2009)

[...] yok kalm(l)s : (p. 419)

...... yok kılm(1) : : (p. 478)

(12) Aydin (2011)

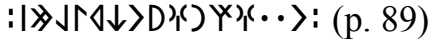

o/u.. $g^{I} S^{I} n^{I} g^{I}$ yok kllmiş (p. 89)

"<...> yok etmiş [allegedly he annihilated]." (p. 90)

(13) Ölmez (2012)

: $|\gg\rangle \Gamma \Delta \downarrow\rangle D)() Y)(4 \ldots:$ : (p. 285)

$\therefore$...rgasanıg yo $\mathrm{k} \mathrm{k \imath lmıs}:$ (p. 273)

“... yok etmiş [allegedly he annihilated].” (p. 279)

(14) Şirin (2016)

[...] yok klm $(\imath)_{S}:($ p. 551)

: w... g $\mathrm{g}^{1} \mathrm{~s}^{1} \mathrm{n}^{1} \mathrm{~g}^{1}$ yok k1lm(1)ş : (p. 654)

\section{Conclusion}

As seen above, the sentence containing the letter group $W \ldots G \check{s} N G$ has been interpreted differently so far:

1. w/o .. $\gamma s^{I} n^{1} \gamma$ yoq qülmï̌s

(1) "he had annihilated ..." (Ramstedt 1913)

(2) "Allegedly he annihilated ...." (Orkun 1936; Aydın 2007, 2011)

(3) (Şirin 2016)

the side of the Tang dynasty or the side of the forces of An-Shi would be a problem. For the movement of the Tang [dynasty] and the Uighur [Khaganate] in the An-Shi Rebellion, see Moriyasu 2002, pp. 130-134. Although Kamalov 2001 also deals with the same theme, one should be careful of some mistakes in the interpretation of historical records."]

The An-Shi Rebellion is the same as the An Lushan Rebellion. An-Shi refers to An Lushan and Shi Siming 史思明 (703-761). 
2. ..... r r yasanï yoq qïlmï̌ "Allegedly he annihilated ...." (Mert 2009; Ölmez 2012)

3. ... y yoq qïlmï "I heard that he annihilated a promising*****" (Moriyasu 1999)

4. onč uruš añiy yoq qilmïs "I heard that he annihilated ***** clan thoroughly"

(Moriyasu et al. 2009)

5. ... yoq qïlmïs/qülmï̌

(1) "he annihilated ..." (Malov 1959; Ajdarov 1971)

(2) "Allegedly he annihilated ..." (Berta 2004)

(3) “... allegedly (he) became nonexistent" (Jeong 2005)

(4) (User 2009; Şirin 2016)

Yoq qil- is a transitive verb meaning 'to annihilate, to destroy'. Therefore, the translation of Jeong (2005) is problematic. Moriyasu et al. (2009) altered a few letters and read it quite differently, therefore their reading is also problematic.

As a transitive verb, it needs a direct object. The accusative case of a noun functions as a definite direct object (Tekin 1968: 127). The accusative suffixes are $-\gamma /-g$ (on the pure stem and the plural stem of a noun) and $-n$ (on the possessive stems) in Orkhon Turkic (Tekin 1968: 127).

The accusative suffix $-\gamma$ is found in this sentence. This $-\gamma$ is the last letter of the first part $(\langle) Y\}(\cdot \cdot\rangle$, i.e. W..GšNG, of the sentence according to Ramstedt, the discoverer and first researcher of this inscription. Thus, the readings without this $-\gamma$ are problematic. There are two completely worn letters between W and G. Therefore, the reading of Berta (2004) is problematic.

The letter $Y$ is used for both $\mathrm{S}$ and $\check{s}$ in the Uighur inscriptions. Incidentally, the letter $>$, i.e. $\mathrm{W}$, seems to be a misreading for ), i.e. $\mathrm{N}$, as can be seen in the following two photographs (Figures 3 and 4).

If that is the case, the letter group can be amended as $\lambda(Y)$ ) $[>J])$, i.e.

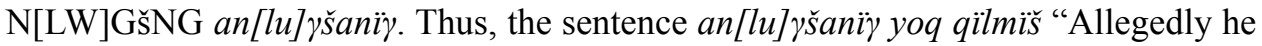

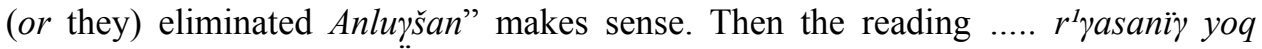
qilmïs of Mert (2009) and Ölmez (2012) is inappropriate.

Anluršan must be the contemporary Turkic $(<$ Chinese) pronunciation of An Lushan 安祿山 (c. 703-757), ${ }^{10}$ who was a general in the Tang dynasty (Tangchao 唐朝, 618-907) and is known for instigating the An Lushan Rebellion (755-763). As is well known, the Uighurs helped the Tang to fight this rebellion and to drive the rebels away from the Tang capital Chang'an 長安.

\footnotetext{
${ }^{9}$ User is the same person as Şirin.
}

${ }^{10}$ The pronunciation of 安祿山 was ?an ləwkşa:n in Late Middle Chinese. It is called Annoksan 안녹산 (<Alloksan 안록산 < Anroksan) in Korean and An Rokuzan あんろくざん in Japanese. Considering the vowel $o$ of the character 祿 lì in Korean and Japanese, it may be more

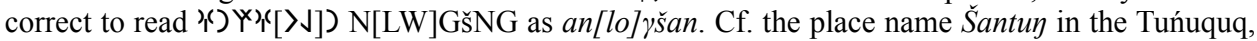
Kül Tegin, and Bilgä Qayan inscriptions (< Chinese Shāndōng 山東; sa:ntəwy in Late Middle Chinese). It is called Sandoy 산동 in Korean and Santō さんとう in Japanese. Considering the vowel $o$ of the character dong 東 in Korean and Japanese, it may be more correct to read the place name in the Orkhon inscriptions as $\check{S} a n t o \eta$, not $\breve{S} a n t u \eta$. 


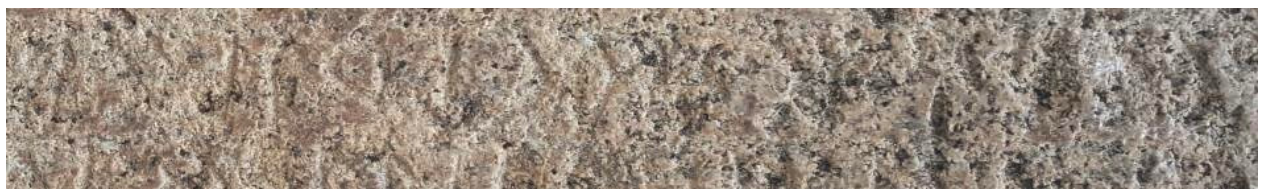

Figure 3. Detail of the West Side of the Šine-Usu Inscription (Photo taken by the author on 1 August 2018)

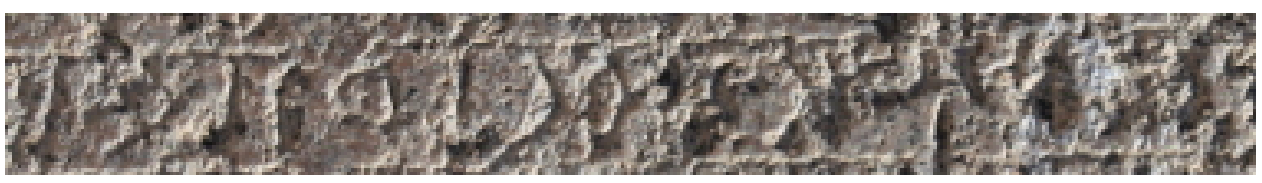

Figure 4. Detail of the West Side of the Sine-Usu Inscription (Photo taken by Byungjae Yoo on 12 August 2016)

At the beginning of a sentence prior to a few severely damaged sentences be-

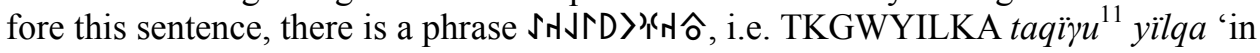
the Fowl year', which corresponds to the year 757. In 757 An Lushan was assassinated by his own son, An Qingxu 安慶緒 (?-759).

In sum, I suggest that the letter groups TKGWYILKA ...... N[LW]GšNGYW

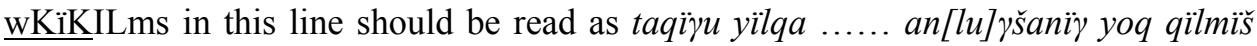
'In the Fowl year (=757), ..... allegedly he (or they) eliminated Anluүšan (= An Lushan)'.

\section{References}

AJDAROv, Gubajdulla [АйдАРОВ, Губайдулла] 1971. Язык орхонских памятников древнетюркской письменности VIII века. Алма-ата: Наука.

AYdin, Erhan 2007. Şine Usu Yazıtı [Šine Usu Inscription]. [KaraM Yayınları 19, Dilbilim Kitaplığı 3.] Çorum: KaraM.

AYDIN, Erhan 2011. Uygur Kăganliğl Yazttlarl [Inscriptions of the Uighur Khaganate]. [Kömen Yayı1nları 74.] Konya: Kömen.

BERTA, Árpád 2004. Szavaimat jól halljátok..., A Türk és Ujgur rovásírásos emlékek kritikai kiadása [Listen to my words well .... Critical edition of the Türk and Uighur runic monuments]. Szeged: JATEPress.

BERTA, Árpád 2010. Sözlerimi İyi Dinleyin..., Türk ve Uygur Runik Yazıtlarının Karşılaştırmalı Ya$y ı n \iota$ [Listen to my words well .... Comparative publication of Turkic and Uighur runic inscriptions]. Translated by Emine YILMAZ. [Türk Dil Kurumu Yayınları 1008.] Ankara: Türk Dil Kurumu.

Clauson, Sir Gerard 1972. An Etymological Dictionary of Pre-Thirteenth-Century Turkish. Oxford: Clarendon Press.

${ }^{11}$ Clauson (1972: 468b): ‘takı:ğu: (etc.) “a domestic fowl”; a very old word both in its natural meaning and as one of the animals in the twelve-year cycle. An early l.-w. in Mong. as takiya (Haenisch 144; Studies, p. 235). C.i.a.p.a.l. [common in all periods and languages] in a bewildering variety of forms, which are set out very fully in Doerfer II 861.' 
Golden, Peter B. 1998. 'The Turkic Peoples: A Historical Sketch.' In: Lars JoHAnson and Éva Á. CsATÓ (eds.) The Turkic Languages. London and New York: Routledge, 16-29.

JEONG Jaehun 정재훈 2005. Wigurǔ Yumokjeguksa 744-840 위구르 유목제국사 744-840 [History of the Uighur nomadic empire 744-840]. [Sŏnam Dongyang Haksul Chongsŏ 31.] Seoul: Moonji Publishing Co.

Malov, Sergey Je. [МАлов, Сергей Е.] 1959. Памятники древнетюркской письменности Монголии и Киргизии. Москва-Ленинград: Издательство Академии Наук СССР.

Mert, Osman 2009. Ötüken Uygur Dönemi Yazıtlarından Tes - Tariat - Şine Us [Tes - Tariat - Šine Us from the Ötükän Uighur period inscriptions]. Ankara: Belen Yayınc1lık Matbaacılık.

MORIYASU Takao 森安孝夫 1999. 'Shineusu iseki, hibun シネウス遺蹟·碑文 [Site and inscription of Šine-Usu].' In: MORIYASU Takao 森安孝夫 and OCHIR オチル (eds.) Mongorukoku genson iseki, hibun chōsa kenkyū hōkoku モンゴル国現存遺蹟·碑文調査研究報告 [Provisional report of researches on historical sites and inscriptions in Mongolia from 1996 to 1998]. Toyonaka: Chūō Yūrashiagaku Kenkyūkai [The Society of Central Eurasian Studies], 177-195.

MORIYASU Takao 森安孝夫 et al. 2009. 'Shineusu hibun yakuchū シネウス碑文訳注 [Šine-Usu Inscription (from the Uighur period in Mongolia: revised text). Translation and commentaries].' Nairiku Ajia gengo no kenkyū 内陸アジア言語の研究 [Studies on the Inner Asian languages] 24: 1-92.

ORKUN, Hüseyin Namık 1936. Eski Türk Yazıtları [Old Turkic inscriptions] I. İstanbul: Devlet Bas1mevi.

ORKUN, Hüseyin Namık 1941. Eski Türk Yazıtları [Old Turkic inscriptions] IV. İstanbul: Alâeddin Kıral Basımevi.

ÖLmEZ, Mehmet 2012. Orhon-Uygur Hanlı̆̆ Dönemi Moğolistan'daki Eski Türk Yazıtları, MetinÇeviri-Sözlük [Old Turkic inscriptions in Mongolia from the Orkhon-Uighur Khanate period: text, translation, glossary]. Ankara: BilgeSu Yayıncilik.

Pulleyblank, Edwin G. 1991. Lexicon of Reconstructed Pronunciation in Early Middle Chinese, Late Middle Chinese, and Early Mandarin. Vancouver: UBC Press.

RAMStEDT, G[ustav] J[ohn] 1913. 'Zwei uigurische Runeninschriften in der Nord-Mongolei.' Journal de la Société Finno-Ougrienne 30/3: 1-63.

RÓNA-TAS, András 1998. 'Turkic Writing Systems.' In: Lars JOHANSON and Éva Á. CsATó (eds.) The Turkic Languages. London and New York: Routledge, 126-137.

ŞiRin, Hatice 2016. Eski Türk yazıtları söz varlı̆̆ incelemesi [Vocabulary analysis of Old Turkic inscriptions]. [Türk Dil Kurumu Yayınları 1181.] Ankara: Türk Dil Kurumu. [Also see Hatice Şirin USER.]

Tekin, Talat 1968. A Grammar of Orkhon Turkic. [Indiana University Publications, Uralic and Altaic Series 69.] Bloomington: Indiana University and The Hague: Mouton \& Co.

TEkin, Talat 2000. Orhon Türkçesi Grameri [A grammar of Orkhon Turkic]. [Türk Dilleri Araştırmaları Dizisi 9.] Ankara: (Sanat Kitabevi) (second edition 2003 in İstanbul).

Tekin, Talat 2016. Orhon Türkçesi Grameri [A grammar of Orkhon Turkic]. [Türk Dil Kurumu Yayınları 1195.] Ankara: Türk Dil Kurumu.

TEKin, Talat and Mehmet ÖLmEz 1999. Türk Dilleri - Giriş [Turkic languages - introduction]. İstanbul: Simurg.

USER, Hatice Şirin 2009. Köktürk ve Ötüken Uygur Kağanlı̆̆ Yazıtları [Inscriptions of the Köktürk and Ötükän Uighur Khaganates]. [Kömen Yayınları 32, Türk Dili Dizisi 1.] Konya: Kömen. [Also see Hatice Şíín.] 